\title{
KIOBEL AND CORPORATE COMPLICITY- RUNNING WITH THE PACK
}

\author{
By Anne Herzberg*
}

Many human rights activists have lamented the outcome of Kiobel v. Royal Dutch Petroleum Co. ${ }^{1}$ Reacting to the opinion, Human Rights Watch expressed concern that Kiobel "significantly reduce[s] the possibility that corporations can be held accountable in US courts for

* Anne Herzberg is the Legal Adviser of NGO Monitor, the Jerusalem-based research institute.

${ }^{1}$ Kiobel v. Royal Dutch Petroleum Co., 133 S.Ct. 1659 (2013). 
human rights abuses committed abroad." 2 The Center for Constitutional Rights issued a statement that it was "deeply troubled by the Supreme Court's decision to undercut 30 years of jurisprudence." Similarly, Amnesty International characterized the opinion as a "radical departure from its own precedent and a decision that ... flies in the face of the trend toward enhancing accountability for serious human rights violations." ${ }^{4}$

Rather than opposing a well-settled international legal norm, however, the Supreme Court's decision actually appears to align with domestic jurisprudence elsewhere in North America and Europe. The courts in these diverse cases have expressed, in various ways, a reluctance to find an international rule of liability: although a few cases are still pending, almost all these cases have been dismissed based on application of justiciability doctrines and other non-merits grounds. ${ }^{5}$

This article briefly examines three civil cases filed in Canada and France. It also looks at two prosecutorial decisions on criminal complaints filed by activists in the Netherlands and Switzerland. In each of these examples, claims of corporate complicity in human rights abuses have not been allowed to proceed.

\section{Canada}

In January 2012, in Anvil Mining Ltd. v. Canadian Ass'n Against Impunity, the Court of Appeal of Québec dismissed a suit filed by the Canadian Association Against Impunity (CAAI) seeking damages against Anvil Mining for being an accomplice in war crimes and crimes against humanity. ${ }^{6}$ Anvil had registered as a corporation in 2004 in Canada's Northwest Territories and, at the time of the lawsuit's filing, was headquartered in Australia and had a small office in Quebec. ${ }^{7}$ Its sole activity was the operation of a copper mine in the Democratic Republic of Congo (DRC). CAAI alleged that Anvil contributed logistical support to the DRC military during a 2004 massacre of civilians in a town located $55 \mathrm{~km}$ from Anvil's mine. ${ }^{8}$ In

\footnotetext{
${ }^{2}$ Human Rights Watch, US: Supreme Court Limits Suits Against Rights Abusers Abroad (Apr. 29, 2013), at http://www.hrw.org/news/2013/04/29/us-supreme-court-limits-suits-against-rights-abusers-abroad.

${ }^{3}$ Center for Constitutional Rights, Kiobel Decision: Supreme Court Limits US Courts' Ability to Use Human Rights Law to Address Human Rights Abuses Committed Abroad (Apr. 17, 2013), at http://www.ccrjustice.org/ newsroom/press-releases/kiobel-decision\%3A-supreme-court-limits-us-courts\%E2\%80\%99-ability-use-humanrights-law-address-human-rights-a.

${ }^{4}$ Amnesty International, US: Supreme Court Ruling on Shell in the Niger Delta Severely Limits Access to Justice in Human Rights Cases (Apr. 17, 2013), at https://www.amnesty.org/en/for-media/press-releases/us-supremecourt-ruling-shell-niger-delta-severely-limits-access-justice-hu; see also ARVNID GANESAN, HUMAN RIGHTS WATCH, CORPORATE CRIME AND PUNISHMENT (2012), available at http://www.hrw.org/news/2012/02/28/ corporate-crime-and-punishment; Brief of Amici Curiae International Human Rights Organizations and International Legal Experts in Support of Petitioners, Kiobel v. Royal Dutch Petroleum Co., 133 S.Ct. 1659 (2013) (No. 10-1491), available at http://www.americanbar.org/content/dam/aba/publications/supreme_court_preview/ briefs/10-1491_petitioner_amcu_international.authcheckdam.pdf; Amnesty International, Business and Human Rights (undated), at http://amnesty.org/en/business-and-human-rights; International Commission of Jurists, Business and Human Rights (undated), at http://www.icj.org/themes/business-and-human-rights.

${ }^{5}$ Approximately a dozen civil lawsuits and criminal complaints have been filed in Europe and Canada seeking liability against a corporation for aiding and abetting violations of international humanitarian law, international human rights, and criminal law committed by a foreign state abroad. Almost all have been dismissed; a few cases are still pending. This article summarizes the most recent decisions.

${ }^{6}$ Anvil Mining Ltd. v. Canadian Ass'n Against Impunity, [2012] C.A. 117, para. 81 (Can. Que.), available at http://www.canlii.org/fr/qc/qcca/doc/2012/2012qcca117/2012qcca117.html (in French) [hereinafter CAAI].

${ }^{7}$ See id., paras. 16-17. According to the company's website, Anvil was acquired by Minmetals Resources Ltd. in March 2012. See http://www.anvilmining.com/index2.html.

${ }^{8}$ See CAAI, supra note 6, paras. 21-26.
} 
particular, CAAI claimed Anvil provided rides to the military to the site of the massacre, supplying trucks, drivers, food, and fuel. ${ }^{9}$

The court of appeal rejected CAAI's complaint, finding that the courts in Quebec did not have jurisdiction. The ruling overturned the lower court decision allowing the case to proceed. Specifically, in looking at section 3148 of the Civil Code of Quebec, the court of appeal determined that, to exercise jurisdiction, there must be a "real and substantial connection" to Quebec-requiring presence in the jurisdiction and activity there- out of which the claim arises. ${ }^{10}$ The court decided that jurisdiction did not exist because "Anvil's activity in Quebec has no connection, directly or indirectly, to the 'complicity' in committing 'war crimes' or 'crimes against humanity' during the operation of a mine." ${ }^{11}$ Moreover, the court did not accept CAAI's claims that it could not obtain justice in either the DRC or Australia. It appeared that the only reason that suit was not brought in Australia was due to the difficulty in convincing a lawyer there to take the case. In the court's opinion, this difficulty was not sufficiently compelling for CAAI to bring suit in Quebec under the principle of forum necessitatis. ${ }^{12}$

The Anvil decision was very similar to another case filed in Quebec, Bil'in (Village Council) v. Green Park International Inc. ${ }^{13}$ The lawsuit, filed in 2008 in the Superior Court of Québec, Montreal Division, was brought by the village of Bil'in, located in the West Bank, and the nongovernmental organization (NGO) Al Haq. ${ }^{14}$ The plaintiffs alleged that the defendant companies acted as "agents of the State of Israel" by "aiding, abetting, assisting and conspiring with the State of Israel in carrying out an illegal purpose” by constructing apartments for Israeli civilians near the Green Line, the 1949 armistice line that separates the West Bank from Israel. ${ }^{15}$ The lawsuit was filed after the village had litigated more than six related cases in Israeli courts, in some of which it had prevailed. ${ }^{16}$ Based on statements made by one of the village's attorneys in an $\mathrm{Al}$ Jazeera documentary, the case was apparently brought in Canada to expand the controversy internationally and to generate publicity. ${ }^{17}$ According to an $\mathrm{Al} \mathrm{Haq} \mathrm{researcher,} \mathrm{the}$ NGO originally envisioned filing a criminal suit in Canada but did not get approval to do so

${ }^{9} I d$., para. 26.

${ }^{10}$ See id., paras. 57-58, 67-68. The court's analysis regarding a "real and substantial" connection to Quebec mirrors that of Kiobel which stated that claims must "touch and concern the territory of the United States" to rebut the presumption against extraterritorial application of the Alien Tort Statute. See Kiobel v. Dutch Petroleum Co., 133 S.Ct. 1659, 1669 (2013). CAAI also harkens to Breyer's concurrence in Kiobel requiring that "the defendant's conduct substantially and adversely affect[] an important American national interest." See id. at 1671 (Breyer, J., concurring.). The "touch and concern" principle also factored in the Bil'in case, discussed infra.

${ }^{11}$ See CAAI, supra note 6, para. 85.

12 See id., paras. 96-103. Under the forum necessitatis principle, the Quebec court could exercise jurisdiction only in exceptional circumstances, such as where there is an "absolute impossibility at law or practical impossibility" in bringing suit in the other forum. Id., para. 98.

${ }^{13}$ Bil'in (Village Council) v. Green Park Int'l Inc., No. 500-17-044030-0 (Can. Montreal Sup. Ct. July 7, 2008).

${ }^{14}$ See Al Haq, Press Release: Bil'in Village Council v. Green Park (2009), available at http://www.alhaq.org/ advocacy/targets/accountability/70-bilin-v-green-park/471-bilin-village-council-v-green-park (case overview).

${ }^{15}$ Further Amended and Particularized Motion Introducing a Suit, para. 9, Bil'in (Village Council) v. Green Park Int'l Inc., No. 500-17-044030-0 (Can. Montreal Sup. Ct. Jan. 23, 2009), available at http://www.alhaq.org/ images/stories/PDF/accoutability-files/the_claim.pdf.

${ }^{16}$ See id. at 34-35; see also Defendants' Exception to Dismiss Action, para. 10, Bil'in (Village Council) v. Green Park Int'l Inc., No. 500-17-044030-0 (Can. Montreal Sup. Ct. June 22, 2009) (on file with author).

${ }^{17}$ Courtroom Intifada: How Palestinian Villagers Quest to Regain Lost Land Has Ended in Court (Al Jazeera broadcast June 3, 2009), at http://www.aljazeera.com/programmes/peopleandpower/2009/06/2009621104411512. html. 
from the authorities. ${ }^{18}$ Interestingly, several of the plaintiffs did not contend that they had an ownership interest in the lands at issue but asserted, instead, that they were "illegally assigned ... to another local council," thereby placing them outside the village's "municipal jurisdiction." ${ }^{19}$ They claimed that the reassignment was a violation of Article 49(6) of the Fourth Geneva Convention, Article 8(2)(b)(viii) of the Rome Statute of the International Criminal Court, the Canadian Crimes Against Humanity and War Crimes Act, and local Quebec statutes. ${ }^{20}$

On September 18, 2009, the court issued a decision dismissing the lawsuit and awarding partial costs to the defendants. ${ }^{21}$ The court found that the "mere existence of municipal jurisdiction over the Lands does not confer any right to their use nor does it otherwise confer . . a sufficient interest" for standing. ${ }^{22}$ The court also remarked that the plaintiffs "offered no evidence whatsoever to this Court of their alleged ownership of the Lands" or that such land was "confiscated." 23

In addition, the court engaged in a forum non conveniens analysis, determining that Israel was the appropriate forum. ${ }^{24}$ The court further highlighted that "as it is presently framed, [plaintiffs' case] can hardly lead to a just result." 25 Plaintiffs were seeking the demolition of many homes, yet had failed to include the "numerous owners or occupants . . . thereby depriving those persons of the right to be heard, a fundamental tenet on natural justice." ${ }^{26}$ Importantly, the court believed that the plaintiffs were attempting to bypass sovereign immunity laws by omitting Israel as a party, even though they were indirectly seeking an "essential finding that [Israel] is committing a war crime." ${ }^{27}$ Finally, the court noted that the plaintiffs had failed to implead the Canadian attorney general or seek his authorization, as required by Canadian law. The court concluded that the plaintiffs were engaging in "inappropriate forum" shopping and had simply chosen a Quebec forum to "avoid[] the necessity . . of proving [their case in Israel] ... thus ensuring for themselves a juridical advantage based on a merely superficial connection of the Action with Québec."28

On August 11, 2010, the court of appeal issued a decision affirming the lower court's dismissal. The court of appeal reiterated the finding that plaintiffs' assertions of an ownership interest in the lands were contradictory and that the plaintiffs were apparently just seeking a

\footnotetext{
${ }^{18}$ John Reynolds, Remarks at the Accountability for IHL Violations Forum, Al Quds University, Jerusalem (Mar. 2009).

${ }^{19}$ Further Amended and Particularized Motion, supra note 15, para. 13.

${ }^{20}$ See id., paras. 15-22.

${ }^{21}$ Bil'in (Village Council) v. Green Park Int'l Inc., No. 500-17-044030-0, Judgment (Can. Montreal Sup. Ct. Sept. 18, 2009) (Cullen, J.), available at http://www.jugements.qc.ca/php/decision.php?liste $=39887605 \&$ doc $=$ 0FB6ADF4D6C912C6AF300DBAD4E2C354A4831D66A546FCD5167EA497485443FF [hereinafter Bil'in Trial Judgment].

${ }^{22} I d$., para. 139.

${ }^{23} I d$., paras. $299-300$.

${ }^{24}$ Id., para. 335; see also Kiobel v. Royal Dutch Petroleum Co., 133 S.Ct. 1659, 1674 (Breyer, J., concurring) (suggesting reliance on the principles of exhaustion, forum non conveniens, and comity to "minimize international friction").

${ }^{25}$ Bilin Trial Judgment, supra note 21, para. 317.

${ }^{26} \mathrm{Id}$.

${ }^{27} \mathrm{Id}$.

${ }^{28} I d$., paras. $326,327$.
} 
judicial "declaration on the policy of the "occupying state." 29 The court agreed with the forum non conveniens analysis, noting that "[i]t requires a great deal of imagination to claim that the action has a serious connection with Quebec." ${ }^{30}$ In March 2011, the Canadian Supreme Court affirmed the lower court decisions by dismissing the suit with costs. ${ }^{31}$ Undeterred, attorneys for the village filed a complaint in February 2013 with the UN Human Rights Committee, claiming that Canada had violated provisions of the International Covenant on Civil and Political Rights by not allowing the case to proceed. ${ }^{32}$

\section{France}

In March 2013, a French appellate court dismissed a lawsuit brought by the Palestine Liberation Organization (PLO) and the Palestinian activist group Association France-Palestine Solidarité (AFPS) against three French companies: Alstom, Alstom Transport, and Veolia Transport. ${ }^{33}$ The PLO and AFPS accused the companies of violating international law by participating in contracts to build the Jerusalem light rail, a portion of which travels through North Jerusalem, deemed by these organizations to be occupied territory. ${ }^{34}$ Specifically, the Palestinians claimed that these contracts violated Israel's obligations under the Geneva and Hague Conventions, as well as the UN Global Compact ${ }^{35}$ signed by the companies. Among other demands, the claimants sought an order annulling the contracts, thereby prohibiting continuing performance, and barring the companies from entering into any subsequent agreements. $^{36}$

The court rejected these demands, finding both a lack of standing and a failure to allege a cause of action. At the outset of the decision, the court ruled that the AFPS did not have standing to bring suit because it was not "defending a collective interest specific to its membership as distinct from the public interest of Palestinians in general." 37 Next, the court considered whether an unlawful act had even been alleged. In particular, the court noted that building the

\footnotetext{
${ }^{29}$ Bil'in (Village Council) v. Green Park Int'l Inc., [2010] C.A. 1455, para. 51 (Can. Que.), available at http:// www.jugements.qc.ca/php/decision.php?liste $=69437636 \&$ doc $=$ 227F3616B495ADDF20D4DEA0A5D509 505A8C1759ED918A3F747A3C483979FAE2\&page $=1$.

${ }^{30} \mathrm{Id}$., para. 86.

${ }^{31}$ Bil'in (Village Council) v. Green Park Int'l Inc., [2011] 1 S.C.R. vi (Can.) (dismissing application with costs), available at http://scc.lexum.org/decisia-scc-csc/scc-csc/scc-l-csc-a/en/item/10463/index.do.

32 See Individual Complaint to the Human Rights Committee Under the Optional Protocol to the International Covenant on Civil and Political Rights, Bil'in (Village Council) v. Canada (Feb. 28, 2013), available at http:// globalinitiative-escr.org/wp-content/uploads/2013/03/130228-NRC-Individual-Complaint-ICCPR-CanadaETOs-FINAL.pdf; see also Tom Blackwell, West Bank Village Accuses Canada of Breaking Human-Rights Laws, NAT'L POST (Can.), June 7, 2013, at http://news.nationalpost.com/2013/06/04/west-bank-village-accusescanada-of-breaking-human-rights-laws.

${ }^{33}$ Association France-Palestine Solidarité v. Société Alstom Transport SA, Judgment, Cour d'appel de Versailles de 22 mars 2013, available at http://www.dreuz.info/2013/04/la-cour-dappel-de-versailles-olp-c-alstom-et-veoliadeclare-que-loccupation-par-israel-nest-pas-illegale (English translation available online at http://www.intjewish lawyers.org/main/files/Versailles\%20Court\%20of\%20Appeals\%20ruling\%20doc\%20English\%20.pdf).

${ }^{34}$ The three companies were not signatories to the contract but had formed an Israeli company that subsequently won the government tender to build the light rail. The companies were also involved in its construction and maintenance.

${ }^{35}$ At http://www.unglobalcompact.org.

${ }^{36}$ Association France-Palestine Solidarité, supra note 33, at 5-6.

$37 \mathrm{Id}$. at 17.
} 
Jerusalem light rail was not illegal because occupation law allows for the governance of occupied territory and includes the building of transportation infrastructure. ${ }^{38}$ Moreover, it emphasized that the determination of the legality of a contract cannot hinge on "the individual assessment of a social or political situation by a third party." ${ }^{39}$ Next, like in Bil'in, the court highlighted the failure to name Israel as a party to the lawsuit even though the allegations concerned Israeli actions. The court also looked to whether the legal norms relied upon by the PLO provided nonstate entities with a private right of action and decided that the obligations of the Geneva and Hague Conventions only apply between state parties, foreclosing the PLO from bringing suit. ${ }^{40}$

Although the court found a lack of standing, the court addressed claims by the PLO regarding the existence of an international norm of corporate complicity. The court stated that corporations were not bound by humanitarian and human rights conventions, with the possible exception of those addressing environmental and labor standards. ${ }^{41}$ After finding no cause of action under international treaties, the court rejected claims that customary law provided a basis for liability. ${ }^{42}$ Similarly, the alleged violations did not rise to the level of a jus cogens norm. ${ }^{43}$ The court further noted that reliance on the UN Global Compact was misplaced as it was not a binding legal instrument and that the companies could not be held liable for alleged violations of voluntarily adopted ethical codes. ${ }^{44}$

\section{Netherlands}

In March 2010, Al Haq filed a criminal complaint in the Netherlands against the Dutch company Riwal for alleged complicity "in the commission of war crimes and crimes against humanity . . . through its supply of mobile cranes and aerial platforms for the construction of settlements and the Wall in several locations in the Occupied West Bank." ${ }^{45}$ Al Haq alleged that such activity violated the Geneva Conventions and, consequently, the Dutch International Crimes Act (Wet Internationale Misdrijven). ${ }^{46}$

In May 2013, however, the prosecutor decided that it would not take legal action against the crane lessor or its directors on account of mootness: the company had stated that it was no longer working in Israel and the West Bank. The prosecutor also explained that a significant factor weighing against further investigation was the company's limited contribution to the building of the security barrier and settlements; its cranes and platforms were only used on

38 See id. at 20; see also Raphael Ahern, French Court's Light Rail Ruling Breaks No Legal Ground, Scholars Say, TIMES OF ISRAEL, Apr. 29, 2013, at http://www.timesofisrael.com/french-ruling-on-jerusalems-light-rail-addsnothing-new-scholars-say.

39 Association France-Palestine Solidarité, supra note 33, at 21.

${ }^{40} \mathrm{Id}$. at 21-22.

41 See id.

${ }^{42}$ See id.

43 See id. at 26-27.

44 See id. at 27-28.

${ }^{45} \mathrm{Al}$ Haq, Criminal Complaint Lodged Against Dutch Company for Construction of Settlements and 'The Wall' (Oct. 14, 2010), at http:/www.alhaq.org/advocacy/targets/accountability/71-riwal/472-criminal-com plaint-lodged-against-dutch-company-for-construction-of-settlements-and-the-wall.

46 See id. 
occasion for a few days and sometimes only through third-party leasing. ${ }^{47}$ Concern also arose related to the complex nature of the case and to the substantial state resources needed should the case proceed. ${ }^{48}$

\section{Switzerland}

Swiss prosecutors from the canton of Vaud announced on May 1, 2013, that it was declining to prosecute Nestlé S.A. and senior managers for alleged complicity in the murder of a trade unionist by paramilitaries in Colombia. In March 2012, the European Center for Constitutional Human Rights (ECCHR) and Colombian NGOs filed a criminal complaint with Swiss authorities claiming that Nestle negligently contributed to the 2005 murder of Luciano Romero, a trade unionist who worked at a local subsidiary of Nestlé until 2002. ${ }^{49}$ The NGOs alleged that the subsidiary's representatives had "falsely branded" Romero as a guerilla fighter, which in the environment of Colombia's armed conflict amounted to a "death sentence." 50 They also claimed that Nestlés local agents were "closely intertwined" with paramilitaries. ${ }^{51}$ The NGOs argued that Nestlé knew of "resulting dangers" to trade unionists and, as a result, had a duty to prevent the crime. ${ }^{52}$ Nestlé responded that no evidence supported the NGO claims and that similar allegations had failed not only in courts in Colombia and the United States but also at the International Labour Organization. ${ }^{53}$

Human rights activists considered the action to be "a European test case" seeking "to demonstrate the extent to which multinational enterprises are to be liable." ${ }^{54}$ On May 1, 2013,

47 Openbaar Ministerie, Geen verder onderzoek naar kraanverhuurder (No further testing for crane hire) (May 14, 2013), at http://www.om.nl/algemene_onderdelen/uitgebreid_zoeken/@160903/verder-onderzoek/. In Kiobel, the British and Dutch governments filed an amicus brief on behalf of Royal Dutch Petroleum. They argued against the exercise of universal jurisdiction and declared that no rule of international law imposed direct liability on corporations. Brief of the Governments of the United Kingdom of Great Britain and Northern Ireland and the Kingdom of the Netherlands as Amici Curiae in Support of the Respondents, Kiobel v. Royal Dutch Petroleum Co., 133 S.Ct. 1659 (2013) (No. 10-1491), available at http://sblog.s3.amazonaws.com/wp-content/uploads/ 2012/02/4587212_1_UK-Netherlands-amicus-brief-ISO-respondents-filed-2-3-12-2.pdf.

48 See Openbaar Ministerie, supra note 47. In response to a parliamentary question regarding involvement of Dutch companies in Israeli settlements, the Dutch government responded that while it considers settlements illegal and discourages Dutch involvement, "Dutch companies are not prohibited to engage in these types of economic relationships. The responsibility lies with the companies themselves." Press Release of the Dutch Government, Questions and Answers, Aanhangsel van de Handelingen, Tweede Kamer der Staten-Generaal (Appendix of Acts, second chamber of the states-general) (Sept. 16, 2013), at https://zoek.officielebekendmakingen.nl/ah-tk20122013-3223.html?zoekcriteria = \%3fzkt\%3dEenvoudig\%26pst\%3d\%26vrt\%3dnegatief\%2bbouw $\% 2$ bad vies\%2bisrael\%26zkd\%3dInDeGeheleText\%26dpr\%3dAfgelopenDag\%26sdt\%3dDatumBrief\%26ap \%3d\% $26 \mathrm{pnr} \% 3 \mathrm{~d} 1 \% 26 \mathrm{rpp} \% 3 \mathrm{~d} 10 \&$ resultIndex $=7 \&$ sorttype $=1$ \&sortorder $=4$.

${ }^{49}$ European Center for Constitutional and Human Rights (ECCHR), Nestlé Has Nothing to Fear from Swiss Legal System, ECCHR SPECIAL NEWSLETTER, May 10, 2013, at 2, available at http://www.ecchr.de/index.php/nestle518.html.

50 Information Platform Human Rights.ch, No Test Case After All—No Charges Filed Against Nestlé in Switzerland (May 29, 2013), available at http://www.humanrights.ch/en/Switzerland/Foreign-Affairs/Foreign-Trade/ Transnational/idart_9188-content.html.

${ }^{51} \mathrm{Id}$.

52 ECCHR, supra note 49, at 2.

${ }^{53}$ Business \& Human Rights Resource Centre, Nestlé Response Re Suit Alleging Its Complicity in Murder of Colombian Trade Unionist (Mar. 7, 2012), available at http://business-humanrights.org/Links/Repository/ 1011578 .

${ }^{54}$ Information Platform Human Rights.ch, supra note 50. 
however, the Swiss prosecutor issued a "no-proceedings order" announcing that an investigation would not be opened because the case was barred by the statute of limitations. ${ }^{55}$ Since the decision, the NGOs and Romero's wife have appealed the order to the cantonal criminal court, claiming that the prosecutors engaged in improper delay in reviewing the case and that the incorrect statute of limitations was applied. ${ }^{56}$

\section{Conclusion}

Emerging jurisprudence in North America and Europe indicates reluctance by courts and prosecutors to proceed with litigation in cases where a corporation is alleged to have aided and abetted human rights abuses by a foreign state abroad. Far from outside the mainstream then, Kiobel seems to be firmly situated within this line of cases. These courts and prosecutors appear uncertain whether corporations are bound by international human rights and humanitarian norms, particularly when only an indirect connection exists to the alleged violations. Furthermore, these courts and prosecutors seem wary to sit in judgment on the activities and policies of other countries or to become embroiled in messy political disputes or international conflicts. As emphasized in Kiobel, "No nation has ever yet pretended to be the custos morum of the whole world." 57 There also appears to be a significant fear of opening the courts to a stream of litigation related to conduct with, at best, a tenuous connection to the jurisdiction. These courts do not want to encourage forum shopping or the circumvention of sovereign immunity laws. For the time being, it is likely that North American and European courts and prosecutors will continue to favor reliance upon justiciability doctrines and other non-merits grounds in cases alleging corporate complicity in foreign state abuses, rather than becoming embroiled in complex disputes that could have far-reaching political and policy consequences. 